\title{
Sustainable and Low Greenhouse Gas Emitting Rice Production in Latin America and the Caribbean: A Review on the Transition from Ideality to Reality
}

\author{
Ngonidzashe Chirinda ${ }^{1}, *$, Laura Arenas ${ }^{1}$, Maria Katto ${ }^{1}$, Sandra Loaiza ${ }^{1}$, Fernando Correa ${ }^{1}$, \\ Manabu Isthitani ${ }^{1}$, Ana Maria Loboguerrero 1,2 (D), Deissy Martínez-Barón 1,2 (D), \\ Eduardo Graterol ${ }^{3}$, Santiago Jaramillo ${ }^{3}$, Carlos Felipe Torres ${ }^{4}$, Miguel Arango ${ }^{5}$, \\ Myriam Guzmán ${ }^{6}$, Ivan Avila ${ }^{6}$, Sara Hube ${ }^{7}$, Ditmar Bernardo Kurtz ${ }^{8}$ (D), Gonzalo Zorrilla 9 (iD, \\ Jose Terra ${ }^{9}$, Pilar Irisarri ${ }^{10}$, Silvana Tarlera ${ }^{11}$, Gabriel LaHue ${ }^{12}$, Walkyria Bueno Scivittaro ${ }^{13}$, \\ Aldo Noguera ${ }^{14}$ and Cimelio Bayer ${ }^{15}$ \\ 1 Centro Internacional de Agricultura Tropical (CIAT), Palmira 6713, Colombia; eelnac@leeds.ac.uk (L.A.); \\ M.Katto@CGIAR.ORG (M.K.); s.p.loaiza@cgiar.org (S.L.); f.correa@cgiar.org (F.C.); \\ m.ishitani@cgiar.org (M.I.); a.m.loboguerrero@cgiar.org (A.M.L.); d.m.baron@cgiar.org (D.M.-B.) \\ 2 Consultative Group on International Agricultural Research (CGIAR) Research Program on Climate Change, \\ Agriculture and Food Security (CCAFS), Palmira 6713, Colombia \\ 3 Fondo Latinoamericano para Arroz de Riego (FLAR), Palmira 6713, Colombia; e.j.graterol@cgiar.org (E.G.); \\ s.jaramillo@cgiar.org (S.J.) \\ 4 Instituto de Hidrología, Meteorología y Estudios Ambientales (IDEAM), Bogotá, 111711, Colombia; \\ carlos.torrestriana@fao.org.co \\ 5 Corporación Colombiana de Investigación Agropecuaria (CORPOICA), Via Puerto López 502007, Colombia; \\ marangoa@corpoica.org.co \\ 6 Federación Nacional de Arroceros (FEDEARROZ), Bogotá 111831, Colombia; \\ patriciaguzman@fedearroz.com.co (M.G.); ivanavila@fedearroz.com.co (I.A.) \\ 7 Instituto de Investigaciones Agropecuarias (INIA), Santiago 7083150, Chile; sara.hube@inia.cl \\ 8 Instituto Nacional de Tecnología Agropecuaria (INTA), Corrientes 3400, Argentina; kurtz.ditmar@inta.gob.ar \\ 9 National Agricultural Research Institute (INIA), Treinta y Tres 33000, Uruguay; gzorrilla@inia.org.uy (G.Z.); \\ jterra@tyt.inia.org.uy (J.T.) \\ 10 Department of Plant Biology, College of Agriculture, University of the Republic, Montevideo 12900, \\ Uruguay; pilaririsarri0@gmail.com \\ 11 Department of Biosciences, College of Chemistry and Science, University of the Republic, Montevideo 11800, \\ Uruguay; starlera@fq.edu.uy \\ 12 Department Plant Sciences; Land, Air and Water Resources, University of California, Davis, CA 95616, USA; \\ gtlahue@ucdavis.edu \\ 13 Embrapa Clima Temperado (CPACT), Pelotas, RS 96010-971, Brazil; walkyria.scivittaro@embrapa.br \\ 14 Ministerio de Agricultura y Ganadería (MAG), Asunción 1329, Paraguay; noguera-arnc@hotmail.com \\ 15 Department of Soil Science, Universidad Federal de Río Grande del Sur (UFRGS), Porto Alegre, \\ RS 91540-000, Brazil; cimelio.bayer@ufrgs.br \\ * Correspondence: n.chirinda@cgiar.org; Tel.: +57-2-4450000
}

Received: 24 November 2017; Accepted: 23 February 2018; Published: 1 March 2018

\begin{abstract}
The burgeoning demand for rice in Latin America and Caribbean (LAC) exceeds supply, resulting in a rice deficit. To overcome this challenge, rice production should be increased, albeit sustainably. However, since rice production is associated with increases in the atmospheric concentration of two greenhouse gases (GHGs), namely methane $\left(\mathrm{CH}_{4}\right)$ and nitrous oxide $\left(\mathrm{N}_{2} \mathrm{O}\right)$, the challenge is on ensuring that production increases are not associated with an increase in GHG emissions and thus do not cause an increase in GHG emission intensities. Based on current understanding of drivers of $\mathrm{CH}_{4}$ and $\mathrm{N}_{2} \mathrm{O}$ production, we provide here insights on the potential climate change mitigation benefits of management and technological options (i.e., seeding, tillage, irrigation, residue management) pursued in the LAC region. Studies conducted in the LAC region show intermittent irrigation or alternate wetting and drying of rice fields to reduce $\mathrm{CH}_{4}$ emissions by
\end{abstract}


$25-70 \%$ without increasing $\mathrm{N}_{2} \mathrm{O}$ emissions. Results on yield changes associated with intermittent irrigation remain inconclusive. Compared to conventional tillage, no-tillage and anticipated tillage (i.e., fall tillage) cause a $21 \%$ and $25 \%$ reduction in $\mathrm{CH}_{4}$ emissions, respectively. From existing literature, it was unambiguous that the mitigation potential of most management strategies pursued in the LAC region need to be quantified while acknowledging country-specific conditions. While breeding high yielding and low emitting rice varieties may represent the most promising and possibly sustainable approach for achieving GHG emission reductions without demanding major changes in on-farm management practices, this is rather idealistic. We contend that a more realistic approach for realizing low GHG emitting rice production systems is to focus on increasing rice yields, for obvious food security reasons, which, while not reducing absolute emissions, should translate to a reduction in GHG emission intensities. Moreover, there is need to explore creative ways of incentivizing the adoption of promising combinations of management and technological options.

Keywords: greenhouse gas emissions; mitigation prospect; nitrous oxide emission; paddy fields; residue management; methane emission

\section{Introduction}

Rice production is increasing in Latin America and the Caribbean (LAC), as the crop is now classified as both a staple and a cash crop in several countries [1-3]. Currently, rice is grown in 26 LAC countries under diverse production systems and agro-climatic conditions [4]. In the LAC region, rice production over the period 2010-2012 is reported to have averaged 26 million tonnes [5], which translates into an estimated US 8.8 billion dollars in revenue [6]. The regional per capita rice consumption increased from $9 \mathrm{~kg}$ of milled rice in 1924-1928 to about $30 \mathrm{~kg}$ in 2008-2010 [2]. To meet increased regional demand for rice, there has been an increase in both productivity (yield per unit area) and planted area [6] however, with a net rice deficit of over 1 million tonnes, the LAC region remains a net rice importer $[4,5])$.

In the LAC region, irrigated rice, rain-fed lowland rice and upland rice are responsible for about $59 \%, 22 \%, 19 \%$ of total rice production in the region respectively [2]. Further expansion of rice production is still possible in countries such as Colombia and Venezuela, which have substantial land and water resources [7]. There is also a possibility to expand lowland rice production to wetlands in Brazil, Bolivia, Ecuador, Peru, Venezuela, Argentina, Paraguay, Uruguay, Guyana and Central America [2]. However, as irrigated and lowland rice production expands, an increase in $\mathrm{CH}_{4}$ emissions is expected.

Irrigated lowland rice production is a significant anthropogenic source of methane $\left(\mathrm{CH}_{4}\right)$ and nitrous oxide $\left(\mathrm{N}_{2} \mathrm{O}\right)$, two important greenhouse gases (GHGs). Methane, which accounts for $20-30 \%$ of the global warming effect, is second only to carbon dioxide $\left(\mathrm{CO}_{2}\right)$ as the most significant GHG [8]. Methane from rice fields represents about $10 \%$ of non- $\mathrm{CO}_{2}$ emissions from agriculture [8] and about $89 \%$ of the global warming potential (GWP) from rice [9]. The current understanding of the mechanisms responsible for soil $\mathrm{CH}_{4}$ dynamics, including the influence of soil properties and dynamic conditions, has been documented in several previous reviews [10-12]. Basically, the source or sink strength of an environment depends on the balance between methanogenesis and methanotrophy. Methanogenesis is the dominant process under flooded conditions, while $\mathrm{CH}_{4}$ consumption becomes more important in drained soils. The $\mathrm{CH}_{4}$ that is released to the atmosphere escapes through three pathways: diffusion of dissolved $\mathrm{CH}_{4}$ gas, loss through ebullition (gas bubbles), and mainly (80-98\%) by plant transport through the aerenchyma [13-15]. Variations in the quantities of $\mathrm{CH}_{4}$ emitted from rice production systems depend on variations in the amounts of labile carbon from root exudates, sloughed root cells, mucilage and litter (the main sources of substrate for methanogenesis), soil oxygen dynamics, 
soil characteristics such as iron oxides and nitrogen content and differences in rice aerenchyma structure $[13,16-18]$

In addition to $\mathrm{CH}_{4}$ emissions, agricultural soils contribute approximately $60 \%$ of anthropogenic $\mathrm{N}_{2} \mathrm{O}$ emissions, which account for about $6 \%$ of total anthropogenic radiative forcing [19]. Several previous reviews give detailed accounts on the mechanisms responsible for soil $\mathrm{N}_{2} \mathrm{O}$ dynamics [20-22]. Under flooded conditions, soil $\mathrm{N}_{2} \mathrm{O}$ emissions are generally lower than those from aerobic soils as, in the former, denitrification tends to be complete, thus releasing dinitrogen $\left(\mathrm{N}_{2}\right)$ gas [9]. In addition, if urea, ammonium or ammonia-based fertilizers are applied, the flooded conditions may prevent nitrification and thus limit substrate availability for denitrification and therefore $\mathrm{N}_{2} \mathrm{O}$ emissions. Draining of paddy rice fields may increase $\mathrm{N}_{2} \mathrm{O}$ losses by increasing nitrification and incomplete denitrification [15,23-25]. A recent study conducted in Uruguay (Illarze et al. [26]) highlighted that soil type and drainage management had a strong influence on soil $\mathrm{N}_{2} \mathrm{O}$ emissions. Specifically, soils with higher organic matter content exhibited higher denitrifier activity and thus showed higher soil $\mathrm{N}_{2} \mathrm{O}$ emissions. End of season drainage also resulted in high soil $\mathrm{N}_{2} \mathrm{O}$ emissions.

To reduce the rice deficit in LAC and increase food security, the region needs to further increase the area under rice production and/or increase productivity. However, it is important that increased rice outputs are not associated with increases in GHG emissions. This is particularly important if we consider that, under the 2015 Climate Agreement, several LAC countries have committed to reduce their economy-wide GHG emissions, including those from the agriculture sector [27]. However, we must hasten to mention that reductions in yield-scaled GHG emissions will not necessarily enable countries to reach their IPCC targets unless absolute emissions also decline.

In recent years, there has been an increase in the number of studies aimed at quantifying GHG emission from rice systems in LAC $[25,28-33]$. The aim of this review is to explore the state of knowledge of GHG emissions and mitigation strategies for rice systems in LAC. Besides identifying pragmatic options for reducing GHG emissions from rice production systems, we aim to understand knowledge gaps in the GHG mitigation potential of rice systems in LAC and discuss possibilities for making rice production systems in LAC more sustainable.

\section{Contrasting LAC to Asia Rice Production Systems}

In this review, we will compare and contrast the LAC region with Asia-the most important rice growing region in terms of both the area under rice production and the volume of rice produced [2]. Table 1 shows rice statistics for the five main rice producer countries in Asia and LAC [2,34].

Table 1. Mean (2004-2014) rice statistics in the main rice producer countries in Asia and Latin America and the Caribbean (LAC) (Source: FAOSTAT, [35]).

\begin{tabular}{ccccc}
\hline Country & $\begin{array}{c}\text { Harvested Area } \\
\text { (million ha) }\end{array}$ & $\begin{array}{c}\text { Total Production } \\
\text { (million tonnes) }\end{array}$ & $\begin{array}{c}\text { Yields } \\
\text { (tonnes ha }\end{array}$ & $\begin{array}{c}\mathbf{C H}_{\mathbf{4}} \text { Emissions } \\
\text { (tonnes } \mathbf{C H}_{\mathbf{4}} \mathbf{h a}^{-\mathbf{1}} \text { ) }\end{array}$ \\
\hline India & 43 & 146 & 3.4 & 0.11 \\
China & 29 & 195 & 6.5 & 0.18 \\
Indonesia & 12 & 63 & 4.9 & 0.21 \\
Bangladesh & 11 & 46 & 4.2 & 0.10 \\
Viet Nam & 7 & 40 & 5.3 & 0.18 \\
Brazil & 2 & 12 & 4.3 & 0.06 \\
Colombia & 0.5 & 2 & 4.6 & 0.21 \\
Peru & 0.4 & 3 & 7.2 & 0.24 \\
Argentina & 0.2 & 1 & 6.6 & 0.28 \\
Uruguay & 0.2 & 1 & 7.6 & 0.28 \\
\hline
\end{tabular}

The size of farm holdings among rice farmers in Asia is generally smaller $(<5$ ha per household) than the predominantly highly-mechanized commercial farms of LAC ( $>10$ ha per household) [2]. In both regions, a variety of land preparation techniques ranging from no-tillage, minimum tillage, 
dryland conventional tillage (i.e., disc plowing and leveling operations) and wet tillage (puddling) are practiced by rice producers. Generally, conventional tillage on dry soil conditions is common in LAC while puddling is common in Asia. The LAC farmers mainly practice direct seeding and those in Asia predominantly practice the labor-intensive rice transplanting system. In both regions, quantitative estimates of rice straw amounts and utilization are limited. Nonetheless, rice straw is mainly either burnt (through open-field burning or used as a fuel for cooking) or incorporated into the soil and to a limited extent used for field mulching, animal bedding or livestock feeding [35].

An overview on GHG emissions and emission intensities from rice production systems in Asia and LAC was determined using FAOSTAT data [5] (Figure 1). Emissions reported in Figure 1 were quantified using activity data disaggregated into irrigated, rain-fed and upland water regimes. Where available, country specific emission factor $(\mathrm{EF})$ values were used [36]. For Asian countries with no default $\mathrm{EF}$ value, an area-weighted average $\mathrm{EF}\left(15.7 \mathrm{~g} \mathrm{CH}_{4} \mathrm{~m}^{-2} \mathrm{yr}^{-1}\right)$ was used. For the LAC region, the global Intergovernmental Panel on Climate Change (IPCC) EF value $\left(20 \mathrm{~g} \mathrm{CH}_{4} \mathrm{~m}^{-2} \mathrm{yr}^{-1}\right)$ was used. The EF values were modified by the application of a scaling and correction factor for water regimes and organic amendments, respectively. According to FAOSTAT, a scaling factor of 0.7 was used for rain-fed rice and 0 for upland rice or dry conditions [37]. In addition, for the FAOSTAT data, a default correction factor of 2 was used for organic amendments for all countries [37] Results from this very coarse data suggest that emissions are lower in Brazil that in the other major rice producing countries in Asia and LAC. However, results from field studies conducted in the LAC region indicate wide variation in methane emissions $\left(0.3-64 \mathrm{~g} \mathrm{CH}_{4} \mathrm{~m}^{-2} \mathrm{yr}^{-1}\right)$ suggesting that over-reliance on the IPCC's default emission factors may either overestimate or underestimate GHG emissions from rice production systems in the different LAC countries. In the next section, we will discuss how several of the technological options and management practices used by rice farmers may influence GHG emissions in LAC countries.

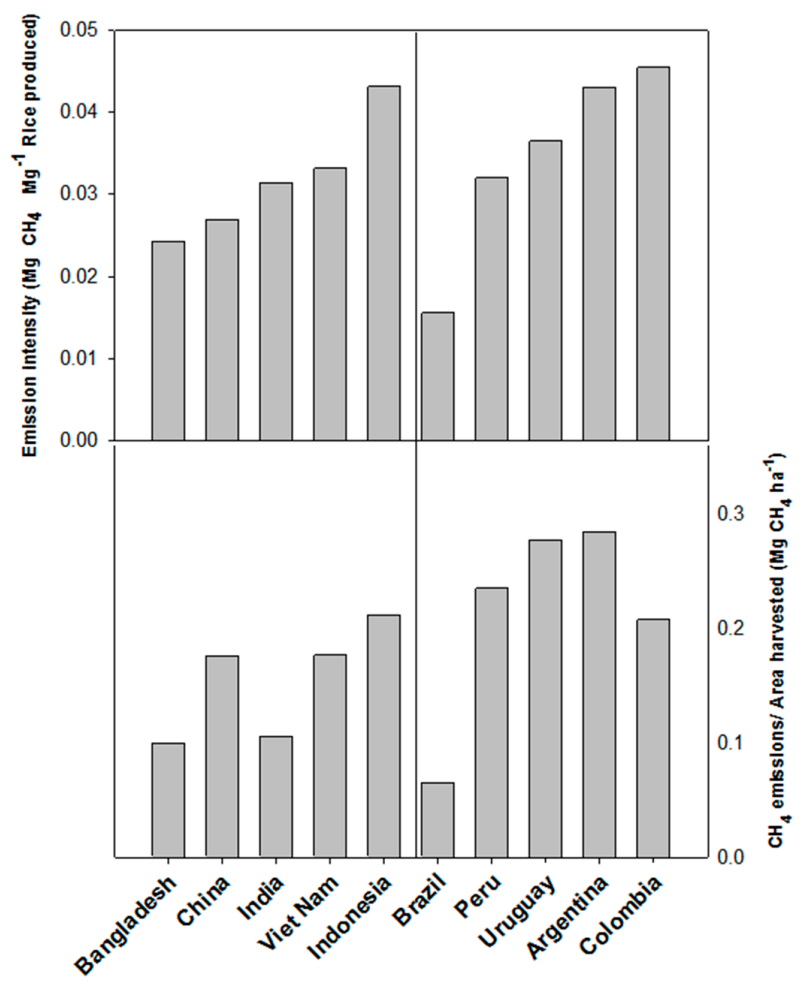

Figure 1. Mean methane emissions per unit rice production and per area in the main rice producing countries in Asia and Latin America and the Caribbean. These values were generated using rice statistics from FAOSTAT [5], which were disaggregated according to irrigated, rainfall and upland water regimes. 


\section{Mitigation Actions That Have Been Studied in LAC}

\subsection{Soil Tillage Practices}

To the best of our knowledge, the effect of tillage systems on GHG emissions from rice fields has been investigated in LAC in only three studies conducted in Brazil. In one of these studies that was conducted in the state of Goiás, a clayey Oxisol reported a 39\% reduction in $\mathrm{CH}_{4}$ emissions in no-tillage compared to disc-ploughed plots [38]. Two of the studies were conducted on a loamy soil in Southern Brazil, and they report a potential to mitigate $\mathrm{CH}_{4}$ emissions by $21 \%$ with adoption of a no-till system and by $25 \%$ with fall tillage in comparison with the spring conventional tillage [31,32]. Bayer et al. [31,32] concluded that biomass incorporation under spring conventional tillage is the main cause of the higher $\mathrm{CH}_{4}$ emissions, implying that rice production systems where residue incorporation is excluded (no-till) may contribute to mitigation of GHG emissions from South Brazilian rice fields. The same conclusion resulted from the anticipation of conventional tillage (plow and disking) from spring to fall, where a significant portion of labile $C$ from rice straw is decomposed under aerobic soil conditions during the off-season (fall and winter), which produces $\mathrm{CO}_{2}$ emissions and decreases the amount of available labile $\mathrm{C}$ to act as substrate for $\mathrm{CH}_{4}$ production under flooded conditions [32]. There is also evidence in the literature that suggests that soil compaction in no-till soils may increase the soil residence time of $\mathrm{CH}_{4}$ thus increasing the probability of its oxidation by methanotrophic bacteria and reducing emission through the rice plant [39]. Similarly, studies conducted in other regions have also reported significant reductions in $\mathrm{CH}_{4}$ emissions (21-60\%) from no-till compared to tilled fields [40,41]. Ali et al. [42] report further reductions (54\%) of $\mathrm{CH}_{4}$ emissions from no-till fields when soils were amended with silicate fertilizer.

Bayer et al. [31] observed similar soil $\mathrm{N}_{2} \mathrm{O}$ emissions under no-till and conventional tillage systems. This result corroborates Zhang et al. [43], who reported similar $\mathrm{N}_{2} \mathrm{O}$ emissions under no-till and conventional tillage in a field experiment conducted in the Jiangsu province of China. However, for a study conducted in the Hubei Province of China, $\mathrm{N}_{2} \mathrm{O}$ emissions were $33 \%$ higher in fertilized no-till compared to fertilized conventional tillage fields [41]. The authors attribute the higher soil $\mathrm{N}_{2} \mathrm{O}$ emissions in the no-till systems to fertilizer exposure on the soil surface, resulting in increased nitrification, and also higher denitrification due to higher soil bulk density (lower total pore volume) and, possibly, increased anaerobic conditions in the topsoil.

Statistics on the extent of the different types of tillage practices conducted by rice farmers in LAC countries are limited. However, about $50 \%$ of the cropping area under no-tillage is reported to be in the LAC region where some countries have about $70 \%$ of their total cultivated area, including rice fields, under no-tillage [44]. This implies that both the knowledge and the technical capacity to conduct no-tillage farming exist in the region. Considering that no-tillage systems have the potential of reduce $\mathrm{CH}_{4}$ emissions from rice fields, quantification of the area under this practice and other tillage systems would enable better estimates of tillage induced regional emissions from the rice sector.

\subsection{Nitrogen Fertilizer Management}

The application of nitrogen $(\mathrm{N})$ fertilizer to agricultural soils increases productivity and may also influence GHG emissions from rice systems. In a meta-analysis conducted by Linquist et al. [45], $\mathrm{N}$ fertilizer-induced $\mathrm{N}_{2} \mathrm{O}$ emissions were reported to be $0.21 \%$ under continuous flooding and $0.40 \%$ under alternate wetting and drying (AWD) rice production systems. In the same meta-analysis an effect of fertilizer type was reported, with $\mathrm{N}_{2} \mathrm{O}$ emissions shown to increase by $24 \%$ and $\mathrm{CH}_{4}$ emissions to decrease by $40 \%$ when urea was replaced by ammonium sulphate. However, in soils under irrigated rice, the relationship between $\mathrm{N}$ fertilizer and $\mathrm{CH}_{4}$ is multifaceted [46]. Nitrogen fertilizer increases plant growth and may also increase the quantity of crop residues and root exudates which supply carbon substrate for methanogenesis [46,47]. Moreover, similarities in size and structure between $\mathrm{CH}_{4}$ and $\mathrm{NH}_{4}{ }^{+}$may result in the latter inhibiting $\mathrm{CH}_{4}$ consumption [48]. In a field experiment conducted in China, increasing the rates of ammonium sulphate and urea fertilizer from 100 to $300 \mathrm{~kg} \mathrm{~N} \mathrm{ha}^{-1}$ 
decreased $\mathrm{CH}_{4}$ emissions by 30 and 7\%, respectively [49]. However, a decrease in $\mathrm{CH}_{4}$ emissions with high $\mathrm{N}$ application rates may show tradeoffs with an increase in $\mathrm{N}_{2} \mathrm{O}$ emissions, demonstrating the complexity of interactions between $\mathrm{N}$-fertilization and $\mathrm{CH}_{4}$ emissions [50].

In the LAC region, research on $\mathrm{N}$ management has focused on increasing $\mathrm{N}$ use efficiency. For instance, a study conducted in Uruguay focused on exploring the $\mathrm{N}_{2} \mathrm{O}$ mitigation potential of a nitrification inhibitor used in rice fields, and showed a decrease in $\mathrm{N}_{2} \mathrm{O}$ emissions and nitrate content in soil about 30 days after sowing; however, in the same study, cumulative $\mathrm{N}_{2} \mathrm{O}$ emissions for the first 35 days were not significantly different between systems with and without nitrification inhibitors [51]. Additionally, in Brazil, evaluations related with $\mathrm{N}$ losses from ammonia volatilization and response to use of a urease inhibitor in rice fields were conducted by Scivittaro et al. [52], who reported that the urease inhibitor can reduce the ammonia volatilization by 83 to $88 \%$ in muddy and moist soils. A greenhouse experiment conducted in Uruguay reported that early flooding in combination with nitrogen fertilization tends to increase soil $\mathrm{N}_{2} \mathrm{O}$ emissions [30]. In the same study [30], there was evidence that the use of cover crops (i.e., ryegrass) in combination with fertilization may increase GHG emissions during the rice production cycle.

\subsection{Water Management}

Water management influences rice production and $\mathrm{CH}_{4}$ and $\mathrm{N}_{2} \mathrm{O}$ emissions from rice systems. Single or multiple drainages during a rice growing season (e.g., AWD) are reported to reduce $\mathrm{CH}_{4}$ emissions by 48 to $93 \%$ compared to those observed under continuous flooding systems [53-57]. Several studies conducted in LAC have reported a decrease in $\mathrm{CH}_{4}$ emissions for AWD compared to continuous flooding: in Uruguay a 55\% decrease was observed [58] and in Brazil a 25-45\% decrease was seen with intermittent irrigation [25,29]. A recent study conducted in Colombia reported a $70 \%$ decrease [33]. The reduction in $\mathrm{CH}_{4}$ emissions has been attributed to changes in soil redox conditions $[29,59]$.

The few studies conducted in LAC corroborate with studies conducted in other regions, which show that AWD water management results in a reduction in $\mathrm{CH}_{4}$ emissions from irrigated rice production systems [15,60-62]. A recent incubation study suggests that the structure of soil microbial communities, which changes with water management histories, also affects GHG production [63]. Specifically, Lagomarsino et al. [63] report less abundant methanogens in soils that were never subjected to flooding, which suggests the possibility of decreasing long-term $\mathrm{CH}_{4}$ emissions by adopting management practices that rotate irrigated rice with aerobic crops. Rotating irrigated rice with aerobic crops and pastures, which has several inherent challenges related to managing for different soil properties (e.g., compaction, drainage), has been done in some LAC countries such as Uruguay, Argentina and Brazil. However, GHG emissions from these systems are yet to be adequately quantified.

Although several studies have reported similar $\mathrm{N}_{2} \mathrm{O}$ emissions from soil under either AWD or continuous flooding [53,58,61,64], trade-offs between $\mathrm{CH}_{4}$ and $\mathrm{N}_{2} \mathrm{O}$ emissions have also been widely reported $[49,61,65]$. To concurrently reduce $\mathrm{CH}_{4}$ and $\mathrm{N}_{2} \mathrm{O}$ emissions and, consequently, the GWP of irrigated rice, both water and nitrogen inputs need to be optimized [63]. Therefore, to obtain a more holistic view, future studies in LAC should simultaneously, explore the influence that water and $\mathrm{N}$ fertilizer management practices have on GHG emissions.

In Asia, though the mitigation benefits associated with AWD are well documented, adoption of this water management practice by farmers is still limited despite the many dissemination efforts [66,67]. For instance, Lampayan et al. [68] report that, since 2002, approximately $2 \%$ of the Philippines' total rice area had adopted AWD. In Bangladesh, where AWD was introduced in 2004 and implementation began in 2007, no mass uptake of the technology had been observed by 2010 [69]. One of the main challenges of AWD is related to the possibility of yield reductions, if it is not implemented properly (e.g., if drying is done during critical stages of the plant growth cycle such as flowering). To avoid yield penalties associated with AWD, there is need to improve awareness on good water scheduling approaches and explore new irrigation techniques that allow for proper timing of drying. In 
addition, weed management needs to be adequately adjusted under AWD in order to avoid competition from weeds that are normally suppressed with continuous flooding [70]. More importantly, to promote adoption of AWD, there is need to create an enabling environment with regards to policy and the necessary infrastructure for water pricing delivery and control by farmers [67]. A study conducted in China reported that AWD was adopted on about $40 \%$ of the rice growing area [71]. It appears that water pricing mechanisms, whereby water is priced on a volumetric rather than an area basis, were critical factors in incentivizing the wide-spread adoption of AWD in China. Similar proposals have been made to incentivize AWD adoption in LAC [33], however, as is the case in China, a change in the pricing mechanisms would require strong political will.

The mitigation potential of other water management practices pursued in the region is yet to be quantified. For instance, in Argentina, farmers are generally recommended to suspend irrigation 15-20 days after flowering [72], a management practice that enables farmers to save water and money and may reduce $\mathrm{CH}_{4}$ emissions. Another example is in Colombia, where under the massive technology adoption programme (AMTEC by its Spanish acronym) led by the National Federation of Rice Producers (FEDEARROZ by its Spanish acronym), farmers are encouraged to avoid flooding their fields but to keep their soils saturated throughout the rice growing season by controlled irrigation (similar to aerobic rice) [73]. Recent reports show that at least one component of the AMTEC package had been adopted on about $56 \%$ of the rice growing area [74]. The avoidance of flooding, which is part of the AMTEC package, may lead to a reduction in $\mathrm{CH}_{4}$ emissions; however, these presumed emission reductions are yet to be validated through field measurements.

\subsection{Residue Management}

The amount of rice produced in LAC is estimated at 28 million tonnes, mostly from improved short varieties $[34,75]$. Since the grain to straw ratio of rice ranges from 0.5 for traditional tall varieties to 1.0 for improved short varieties [76], we can assume that similar amounts of straw (28 million tonnes) are produced. With only 4.2 percent of world rice production [77], the LAC region definitely produces less straw than Asia, which may in turn influence GHG emissions. The incorporation of rice residues contributes toward long-term nutrient cycling but may, due to high $\mathrm{C} / \mathrm{N}$ ratios, cause short-term $\mathrm{N}$ immobilization and thus affect $\mathrm{N}$ availability for subsequent crops [78,79]. In a pot experiment conducted in Brazil, Zschornack et al. [80], demonstrated that, compared to residue incorporation, leaving cover crop residues (ryegrass and serradella) on the soil surface minimizes both soil $\mathrm{CH}_{4}$ and $\mathrm{N}_{2} \mathrm{O}$ emissions from irrigated rice. In the same study crop residue type had no significant effect on $\mathrm{CH}_{4}$ but on $\mathrm{N}_{2} \mathrm{O}$ emissions [81]. The open burning of crop residues emits $\mathrm{CO}_{2}, \mathrm{CH}_{4}$ and $\mathrm{N}_{2} \mathrm{O}$, with the magnitude of these emissions depending on straw moisture content at the time of burning [81].

Globally, there is limited published work on GHG emissions from open air burning of agricultural residues. Several cases studies have used the IPCC guidelines, where open burning emissions can be estimated by multiplying the quantity of rice straw subject to open burning with a combustion factor (fraction of the mass combusted during the course of a fire) and emission factors of the different GHGs [82]. While we are not aware of any research in the LAC region that has determined region-specific GHG emission factors from open burning of rice straw, we would not expect GHG emissions from open burning of straw to vary much across regions. However, we expect within the region variations in GHG emissions to be related to differences in straw moisture content as influenced by harvest time, post-harvest rainfall and burning time.

Timing of straw incorporation has been shown to influence $\mathrm{CH}_{4}$ emissions and can be managed to reduce $\mathrm{CH}_{4}$ emissions during the rice growing season [83,84]. Specifically, $\mathrm{CH}_{4}$ emissions have been reported to increase when crop residues are incorporated prior to planting, due to higher amounts of readily available carbon stimulating soil microbial activity [78,85-89] An approach for reducing the amount of $\mathrm{CH}_{4}$ associated with straw incorporation was reported by Sander et al. [84], in a study conducted in Los Baños, Philippines. In this work, the strategy of incorporating rice residues 
immediately after harvest and subsequent aerobic decomposition of the residue before soil flooding (for the next crop) reduced $\mathrm{CH}_{4}$ emissions by 2.5 to 5 times and also improved nutrient cycling.

As mentioned earlier, the incorporation rice straw immediately before planting negatively affects rice yields due to high $\mathrm{N}$ immobilization [79]. This implies a double negative effect of straw incorporation prior to planting the next crop: higher $\mathrm{CH}_{4}$ emissions and lower yields [90]. On the other hand, early incorporation of straw has been reported to be an effective way of increasing soil fertility and reducing $\mathrm{CH}_{4}$ emissions [89]. For example, in the Corrientes region which produces $40 \%$ of Argentina's rice [2], straw from about $85 \%$ of the planted area is incorporated with disks after harvest which could lead to aerobic decomposition and thus could mitigate $\mathrm{CH}_{4}$ emissions, as previously reported in the Philippines [84]

\section{Mitigation Actions That Have Not Been Studied in LAC}

\subsection{Cultivar Choice}

No studies have been conducted on varietal differences in $\mathrm{CH}_{4}$ or $\mathrm{N}_{2} \mathrm{O}$ emissions in LAC. Nonetheless, several previous studies conducted outside of LAC have observed inter-varietal differences in $\mathrm{CH}_{4}$ emissions from rice fields [13,18,91-93]. The varietal differences in emitted $\mathrm{CH}_{4}$ are regulated by the amount of root exudates and degrading roots which influence substrate (i.e., carbon) availability [94]; tiller numbers, leaf area and quantity [95,96]; grain starch content [97]; duration in the field [98] and aerenchyma structure which affects methane transport from the soil to the atmosphere [99]. In contrast, studies conducted outside of LAC have found no varietal differences in soil $\mathrm{N}_{2} \mathrm{O}$ emissions [93]. Even though about $80 \%$ of the total $\mathrm{N}_{2} \mathrm{O}$ produced in the soil is known to be transmitted through the rice aerenchyma, under flooded conditions $[14,100]$, (the low redox potential, under these conditions is associated with complete denitrification, which probably masks cultivar-based differences. However, several of these studies have also reported inconsistencies across sites and seasons suggesting a stronger influence from the environment.

Zheng et al. [101] reported significantly higher yield-scaled GWP in the Indica (1101.72 $\mathrm{kg} \mathrm{CO}_{2}$ equiv. $\mathrm{Mg}^{-1}$ ) compared to Japonica $\left(711.38 \mathrm{~kg} \mathrm{CO}_{2}\right.$ equiv. $\mathrm{Mg}^{-1}$ ) race. They attribute these differences to dissimilar gas transport capacity among these two rice races. The fact that Indica rice varieties are more common in the LAC region suggests a possibility of higher GWP for rice produced in LAC compared to rice produced in Asia, where Japonica rice varieties are common. Research should aim to identify high-yielding rice cultivars with low GWP. This approach is probably the most effective option for mitigating $\mathrm{CH}_{4}$ emissions as, unlike other approaches, it does not require significant changes in farmer practices [102].

\subsection{Seeding Practices}

Direct seeding, whereby seeds are sown in well-prepared dry soil or in association with zero or minimum tillage, is common in LAC [6,103]. Unlike transplanted rice, direct seeding is known to have economic and logistical advantages as it is associated with a reduction in labor costs, field preparation, water demand and nursery establishment [104,105]. It also implies 20 to 40 fewer days of soil saturation by flooding compared with transplanting, directly reducing the favorable conditions for methanogenesis. Evidence from previous studies conducted in Asia suggest that $\mathrm{CH}_{4}$ emissions associated with direct seeding are $8-92 \%$ lower than those under transplanted rice $[106,107]$. In addition, $\mathrm{CH}_{4}$ emission reductions have been observed to be higher for dry-direct seeding compared to wet-direct seeding, a difference which can be attributed to dissimilar periods when fields are subjected to dry conditions [107]. The prevalence of dry direct seeding systems in LAC may lower $\mathrm{CH}_{4}$ emissions relative to Asia, where transplanted rice is common. We are not aware of any studies that have compared greenhouse gas emissions form direct seeding and transplanted rice in the LAC region. 


\section{Summary and Future Perspectives}

In summary, since research on GHG emissions from the rice sector in LAC is still limited to a few countries and management practices (Table 2), there is evidently a need for more research to cover existing information gaps on the environmental impacts of other rice management practices conducted in the region. Since rice production systems and conditions in LAC vary greatly between countries, it is difficult to generalize mitigation actions. Partners in the Global Research Alliance Americas sub-group are exploring the possibility of multi-nation projects to simultaneously quantify the mitigation potential of promising management options. Such studies are expected to provide insights on regional and site-specific variations in GHG emissions.

In our opinion, idealistically, the most effective mitigation strategies should be based on identifying or breeding low-emitting rice varieties. Compared to other management practices, for which adoption could be costly for the farmer, changing seed choices may be easier to implement, especially if the new varieties also have traits for increased productivity (high rice grain harvest index) and adaptation to climate change impacts (e.g., heat stress, water scarcity). Such robust rice varieties would be key to realizing an eco-efficient rice production. While developing rice varieties with ideal characteristics (high yielding and low emitting) is an attractive option, this approach is currently in the realm of ideality and is currently difficult to realize due to the resource-demanding process of variety development. In the short-term, a more realistic approach is that research conducted in the LAC region should continue focusing on increasing rice yields, which we expect to translate into less GHG emissions per kg of rice produced (emission intensity). Focus should also simultaneously be placed on exploring and quantifying the climate change mitigation potential of different technologies and management practices that are currently pursued in the region and elsewhere. A modelling study conducted in Argentina found that, in rice production systems, lower emissions can be achieved through a combination of management practices including conventional tillage, optimal sowing dates, commencing irrigation 10 days after sowing, maintaining a $10 \mathrm{~cm}$ layer of water during the whole growing period and optimal fertilization [108]. More creative approaches as are being pursued in countries such as Argentina, where there are plans to explore the mitigation potential of alternating rice-fish productions systems on current rice fields should also be encouraged.

We anticipate that increasing consumer awareness and influencing consumer preferences towards more sustainably produced rice will also contribute towards incentivizing the adoption of good management and technological choices. However, for these changes to occur, there is a need for improved integration of rice value chain actors. We therefore suggest that rice stakeholders, in all rice-growing LAC countries, may need to invest in exploring creative ways of combining technological, management and policy innovations to ensure that future efforts, from land preparation to rice consumption, aim to both increase productivity and reduce GHG emissions along the rice value chain. Finally, multi-stakeholder platforms such as the Latin American Irrigated Rice Fund (FLAR by its Spanish acronym) should consider working to improve documentation of adoption rates for promising mitigation actions. 
Table 2. Greenhouse gas emission reductions and yield changes observed in studies on climate change mitigation options for rice production systems in Latin America.

\begin{tabular}{|c|c|c|c|c|c|c|c|}
\hline \multirow{2}{*}{$\begin{array}{c}\text { Agronomic } \\
\text { Practice }\end{array}$} & \multirow{2}{*}{ Reference } & \multirow{2}{*}{ Country } & \multirow{2}{*}{ Treatments } & \multirow{2}{*}{$\begin{array}{c}\text { Mitigation } \\
\text { Strategy } \\
\text { Assessment }\end{array}$} & \multicolumn{2}{|c|}{ GHG Reduction (\%) } & \multirow{2}{*}{ Yield Change (\%) } \\
\hline & & & & & $\mathrm{CH}_{4}$ & $\mathrm{~N}_{2} \mathrm{O}$ & \\
\hline \multirow{3}{*}{ Soil tillage } & Bayer et al. [32] & Brazil & CT vs. NT & No tillage & 21 & 3 & -2 \\
\hline & Bayer et al. [33] & Brazil & ST vs. FT & Fall tillage & 24 & - & +4 \\
\hline & Metay et al. [39] & Brazil & OFF vs. DMC & $\mathrm{DMC}$ & 39 & 11 & - \\
\hline \multirow{4}{*}{$\begin{array}{c}\text { Water } \\
\text { management }\end{array}$} & Tarlera et al. [59] & Uruguay & CF vs. AWD & AWD & $57-62$ & - & $-8.2--16$ \\
\hline & Moterle et al. [30] & Brazil & CF vs. II & II & 25 & - & $<1$ \\
\hline & Zschornack et al. [26] & Brazil & CF vs. II regimes & II & $47-71$ & $37-70$ & -1 \\
\hline & Chirinda et al. [34] & Colombia & CF vs. AWD & AWD & 72 & 41 & - \\
\hline \multirow{2}{*}{ Nitrogen fertilizer } & Irrisarri et al. [31] & Uruguay & RCF vs. RC & $\mathrm{RC}$ & 50 & 64 & -11 \\
\hline & Domínguez et al. [52] & Uruguay & Urea-F vs. F + IN & ENTEC & - & NS & -18 \\
\hline $\begin{array}{c}\text { Residue } \\
\text { management }\end{array}$ & Zschornack et al. [81] & Brazil & $\begin{array}{c}\text { Residues } \\
\text { incorporated in } \\
\text { soil vs. residues } \\
\text { left on soil surface }\end{array}$ & left on soil surface & 69 & $71-94$ & - \\
\hline
\end{tabular}

CT: Conventional Tillage; NT: No-Tillage; ST: Spring Tillage; FT: Fall Tillage; OFF: Offset or disc arrowing treatment in which soil was tilled only to 15 cm depth; RC: Rice without fertilization but with cover crop; RCF: rice with cover crop + fertilization; Urea-F; Urea fertilization; ENTEC (fertilizer containing nitrate, ammonium and the nitrification inhibitor DMPP); NS: no significant difference; DMC: Direct Seeding Mulch based treatment with cover crops; CF: Continuous Flooding; AWD: Alternate wetting and drying; II: intermittent irrigation; IN: Nitrification inhibitor. For yield change, a negative sign indicates yield reduction while a positive sign indicates a yield increase. 
Acknowledgments: This work was implemented as part of the Global Research Alliance Paddy Rice Americas sub-group; the Climate and Clean Air Coalition (CCAC); and CGIAR Research Program on Climate Change, Agriculture and Food Security (CCAFS), which is carried out with support from CGIAR Fund Donors and through bilateral funding agreements. For details, please visit https:/ /ccafs.cgiar.org/donors. The views expressed in this document cannot be taken to reflect the official opinions of these organizations.

Author Contributions: As this article contains a review of literature on different aspects of rice production and climate change mitigation and adaptation, authors participated in reviewing literature on different aspects covered in this review: contrasting LAC to Asia rice production systems; soil tillage practices; cultivar choice, seeding practices; nitrogen fertilizer management, water management and straw management. Specifically, the authors contributed as follows: Contrasting LAC to Asia rice production systems-N.C., S.L., L.A., M.K., M.I., G.Z. and S.T.; Soil tillage practices-N.C., S.L., L.A., I.A., S.H. and C.B.; Cultivar choice-L.A., G.Z., S.H., F.C., P.I. and S.T.; Seeding practices-C.B., S.H., L.A. and F.C.; Nitrogen fertilizer management-M.A., I.A., D.B.K., S.T. and P.I.; Water management-G.L., S.J., C.F.T., G.Z., D.B.K. and W.B.S.; C.B., S.H., J.T., and Straw management-M.A., D.B.K., P.I., J.T. and W.B.S. In addition, N.C., A.N., D.M.-B., A.M.L., E.G., M.G. and G.L., contributed towards the introduction as well as the summary and perspective sections.

Conflicts of Interest: The authors declare no conflicts of interest.

\section{References}

1. Nguyen, N.V. Global Climate Changes and Rice Food Security; International Rice Commission Newsletter (FAO): Rome, Italy, 2005; Volume 54, pp. 24-30.

2. GRiSP (Global Rice Science Partnership). 2013 Rice Almanac, 4th ed.; International Rice Research Institute: Los Baños, Philippines, 2013; p. 283.

3. Sanint, L.R. New Rice Technologies for Latin America: Social Benefits, Past Reminiscences and Issues for the Future. Trends CIAT Commod. 1992, 111, 1-35. Available online: http://agris.fao.org (accessed on 10 April 2017).

4. Pulver, E.L. Strategy for sustainable rice production in Latin America and the Caribbean. In Sustainable Rice Production for Food Security, Proceedings of the 20th Session International, Rice Commun, Bangkok, Thailand, 23-26 July 2002; Van Tran, D., Duffy, R., Eds.; FAO: Rome, Italy, 2003; pp. 287-299.

5. FAO. FAOSTAT Rice Market Monitor. Volume XVIII, Issue $\mathrm{N}^{\circ}$ 3, October 2015. 2015. Available online: http: / / www.fao.org/economic/est/publications/rice-publications/rice-market-monitor-rmm/en/ (accessed on 12 April 2017).

6. Martínez, C.P.; Torres, E.A.; Chatel, M.; Mosquera, G.; Duitama, J.; Ishatani, M.; Selvaraj, M.; Dedicova, B.; Tohme, J.; Grenier, C.; et al. Rice breeding in Latin America. In Plant Breeding Reviews; Plant Breeding Reviews, 38; Janick, J., Ed.; Wiley-Blackwell: Hoboken, NJ, USA, 2014; Volume 38, pp. 187-277. ISBN 978-1-118-91683-4.

7. Espinosa, J. Rice Nutrition Management in Latin America. Better Crops Int. 2002, 16, 36-39.

8. IPCC. Climate Change 2014: Mitigation of Climate Change. Contribution of Working Group III to the Fifth Assessment Report of the Intergovernmental Panel on Climate Change; Edenhofer, O., Pichs-Madruga, R., Sokona, Y., Farahani, E., Kadner, S., Seyboth, K., Adler, A., Baum, I., Brunner, S., Eickemeier, P., et al., Eds.; Cambridge University Press: Cambridge, UK; New York, NY, USA, 2014.

9. Linquist, B.A.; Adviento, M.A.; Pittelkow, C.M.; van Kassel, C.; van Groenigen, K.J. An agronomic assessment of greenhouse gas emissions from major cereal crops. Glob. Chang. Biol. 2012, 18, 194-209. [CrossRef]

10. Le Mer, J.; Roger, P. Production, oxidation, emission and consumption of methane by soils: A review. Eur. J. Soil Biol. 2001, 37, 25-50. [CrossRef]

11. Nazaries, L.; Murrell, J.C.; Millard, P.; Baggs, L.; Singh, B.K. Methane, microbes and models: Fundamental understanding of the soil methane cycle for future predictions. Environ. Microbiol. 2013, 15, 2395-2417. [CrossRef] [PubMed]

12. Fazli, P.; Man, H.C.; Shah, U.K.M.; Idris, A. Characteristics of Methanogens and Methanotrophs in Rice Fields: A Review. Asia Pac. J. Mol. Biol. Biotechnol. 2013, 21, 3-17.

13. Butterbach-Bahl, K.; Papen, H.; Rennenberg, H. Impact of gas transport through rice cultivars on methane emission from rice paddy fields. Plant Cell Environ. 1997, 20, 1175-1183. [CrossRef]

14. Yu, K.W.; Wang, Z.P.; Chen, G.X. Nitrous oxide and methane transport through rice plants. Biol. Fertil. Soils 1997, 24, 341-343. [CrossRef] 
15. Hussain, S.; Peng, S.; Fahad, S.; Khaliq, A.; Huang, J.; Cui, K.; Nie, L. Rice management interventions to mitigate greenhouse gas emissions: A review. Environ. Sci. Pollut. Res. 2015, 22, 3342-3360. [CrossRef] [PubMed]

16. Sass, R.L.; Fisher, F.M.; Turner, F.T.; Jund, M.F. Methane emission from rice fields as influenced by solar radiation, temperature, and straw incorporation. Glob. Biogeochem. Cycles 1991, 5, 335-350. [CrossRef]

17. Aulakh, M.S.; Wassmann, R.; Rennenberg, H. Methane transport capacity of twenty-two rice cultivars from five major Asian rice-growing countries. Agric. Ecosyst. Environ. 2002, 91, 59-71. [CrossRef]

18. Lu, W.J.; Wang, H.T.; Huang, C.Y.; Reichardt, W. Communities of iron (III)-reducing bacteria in irrigated tropical rice fields. Microb. Environ. 2002, 17, 170-178. [CrossRef]

19. IPCC. Climate Change 2007: Synthesis Report. Contribution of Working Groups I, II and III to the Fourth Assessment Report of the Intergovernmental Panel on Climate Change; Core Writing Team, Pachauri, R.K., Reisinger, A., Eds.; IPCC: Geneva, Switzerland, 2007; p. 104.

20. Chapuis-Lardy, L.; Wrage-Mönnig, N.; Metay, A.; Chotte, J.L.; Bernoux, M. Soils, a sink for N2O? A review. Glob. Chang. Biol. 2007, 13, 1-17. [CrossRef]

21. Beauchamp, E.G. Nitrous oxide emission from agricultural soils. Can. J. Soil Sci. 1997, 77, 113-123. [CrossRef]

22. Hénault, C.; Grossel, A.; Mary, B.; Roussel, M.; Léonard, J. Nitrous Oxide Emission by Agricultural Soils: A Review of Spatial and Temporal Variability for Mitigation. Pedosphere 2012, 22, 426-433. [CrossRef]

23. Bronson, K.F.; Singh, U.; Neue, H.U. Automated chamber measurements of methane and nitrous oxide flux in a flooded rice soil: II Fallow period emissions. Soil Sci. Soc. Am. J. 1997, 61, 988-993. [CrossRef]

24. Xing, G.X.; Zhao, X.; Xiong, Z.; Yan, X.Y.; Xua, H.; Xie, Y.X.; Shi, S.L. Nitrous oxide emission from paddy fields in China. Acta Ecol. Sin. 2009, 29, 45-50. [CrossRef]

25. Zschornack, T.; da Rosa, C.M.; Pedroso, G.M.; Marcolin, E.; da Silva, P.R.F.; Bayer, C. Mitigation of yield-scaled greenhouse gas emissions in subtropical paddy rice under alternative irrigation systems. Nutr. Cycl. Agroecosyst. 2016, 105, 61-73. [CrossRef]

26. Illarze, G.; del Pino, A.; Riccetto, S.; Irisarri, P. Emisión de óxido nitroso, nitrificación, desnitrificación y mineralización de nitrógeno durante el cultivo del arroz en 2 suelos de Uruguay. Rev. Argent. Microbiol. 2017, 10, 1-8. [CrossRef] [PubMed]

27. UNFCCC.int. The Paris Agreement-Main Page. 2017. Available online: http://unfccc.int/paris_ agreement/items/9485.php (accessed on 30 October 2017).

28. Costa, F.S.; Bayer, C.; de Lima, M.A.; Frighetto, R.T.S.; Macedo, V.R.M.; Marcolin, E. Variação diária da emissão de metano em solo cultivado com arroz irrigado no Sul do Brasil. Ciênc. Rural 2008, 38, 2049-2053. [CrossRef]

29. Moterle, D.F.; da Silva, L.S.; Moro, V.J.; Bayer, C.; Zschornack, T.; Avila, L.A.; CasBundt, A. Methane efflux in rice paddy field under different irrigation managements. Rev. Bras. Ciênc. Solo 2013, 37, 431-437. [CrossRef]

30. Irisarri, P.; Pereyra, V.; Fernández, A.; Terra, J.; Tarlera, $\mathrm{S}$. $\mathrm{CH}_{4}$ and $\mathrm{N}_{2} \mathrm{O}$ Emissions in a rice field: First measurements in the Uruguayan productive system. Agrocienc. Urug. 2012, 16, 1-10.

31. Bayer, C.; Costa, F.S.; Pedroso, G.M.; Zschornack, T.; Camargo, E.S.; Lima, M.A.; Frigheto, R.T.S.; Gomes, J.; Marcolin, E.; Macedo, V.R.M. Yield-scaled greenhouse gas emissions from flood irrigated rice under long-term conventional tillage and no-till systems in a Humid Subtropical climate. Field Crop Res. 2014, 162, 60-69. [CrossRef]

32. Bayer, C.; Zschornack, T.; Pedroso, G.M.; da Rosa, C.M.; Camargo, E.S.; Boeni, M.; Marcolin, E.; Cecilia dos Reis, C.E.S.; dos Santos, D.C. A seven-year study on the effects of fall soil tillage on yield-scaled greenhouse gas emission from flood irrigated rice in a humid subtropical climate. Soil Tillage Res. 2015, 145, 118-125. [CrossRef]

33. Chirinda, N.; Arenas, L.; Loaiza, S.; Trujillo, C.; Katto, M.; Chaparro, P.; Nuñez, J.; Jacobo Arango, J.; Martinez-Baron, D.; Loboguerrero, A.M.; et al. Novel technological and management options for accelerating transformational changes in rice and livestock systems. Sustainability 2017, 9, 1891. [CrossRef]

34. Parra, R.; Escobar, A. Use of fibrous agricultural residues (FAR) in ruminant feeding in Latin America. In Better Utilization of Crop Residues and by-Products in Animal Feeding: Research Guidelines 1. State of Knowledge, Proceedings of the FAO/ILCA Expert Consultation, ILCA Headquarters, Addis Ababa, Ethiopia, 5-9 March 1984; Preston, T.R., Kossila, V.L., Goodwin, J., Reed, S.B., Eds.; FAO: Rome, Italy, 1985.

35. FAO. FAOSTAT Emissions Database, Agriculture, Rice Cultivation. 2016. Available online: http://www.fao. org/faostat/en/\#data/GR (accessed on 11 June 2017). 
36. Intergovernmental Panel on Climate Change (IPCC). Intergovernmental Panel on Climate Change guidelines for National Greenhouse Gas Inventories. In Agriculture: Nitrous Oxide from Agricultural Soils and Manure Management; Chapter 4; OECD: Paris, France, 1997; Available online: http:/ / www.ipcc-nggip.iges.or.jp/ public/gp/english/4_Agriculture.pdf (accessed on 11 June 2017).

37. Intergovernmental Panel on Climate Change (IPCC). Land Use, Land-use Change, and Forestry. A Special Report of the Intergovernmental Panel on Climate Change; Cambridge University Press: Cambridge, UK, 2000; p. 377.

38. Metay, A.; Alves Moreira, J.A.; Bernoux, M.; Boyer, T.; Douzet, J.M.; Feigl, B.; Feller, C.; Maraux, F.; Oliver, R.; Scopel, E. Storage and forms of organic carbon in a no-tillage under cover crops system on clayey Oxisol in dryland rice production (Cerrados, Brazil). Soil Tillage Res. 2007, 94, 122-132. [CrossRef]

39. Li, C.; Hang, Z.; Guo, L.; Cai, M.; Cao, C. Emissions of $\mathrm{CH}_{4}$ and $\mathrm{CO}_{2}$ from double rice cropping systems under varying tillage and seeding methods. Atmos. Environ. 2013, 80, 438-444. [CrossRef]

40. Hanaki, M.; Toyoaki, I.; Saigysa, M. Effect of no-tillage rice (Oryza sativa L.) cultivation on methane emission in three paddy fields of different soil types with rice straw application. Jpn. Soc. Soil Sci. Plant Nutr. 2002, 73, 135-143.

41. Ahmad, S.; Li, C.; Dai, G.; Zhan, M.; Wang, J.; Pan, S.; Cao, C. Greenhouse gas emission from direct seeding paddy field under different rice tillage systems in central China. Soil Tillage Res. 2009, 106, 54-61. [CrossRef]

42. Ali, M.A.; Lee, C.H.; Lee, Y.B.; Kim, P.J. Silicate fertilization in no-tillage rice farming for mitigation of methane emission and increasing rice productivity. Agric. Ecosyst. Environ. 2009, 132, 16-22. [CrossRef]

43. Zhang, X.X.; Yin, S.; Li, Y.S.; Zhuang, H.L.; Li, C.S.; Liu, C.J. Comparison of greenhouse gas emissions from rice paddy fields under different nitrogen fertilization loads in Chongming Island, Eastern China. Sci. Total Environ. 2014, 472, 381-388. [CrossRef] [PubMed]

44. Derpsch, R.; Friedrich, T. Development and Current Status of No-till Adoption in the World. In Proceedings of the CD, 18th Triennial Conference of the International Soil Tillage Research Organization (ISTRO), Izmir, Turkey, 15-19 June 2009.

45. Linquist, B.A.; Adviento-Borbe, M.A.; Pittelkow, C.M.; van Kessel, C.; van Groenigen, K.J. Fertilizer management practices and greenhouse gas emissions from rice systems: A quantitative review and analysis. Field Crops Res. 2012, 135, 10-21. [CrossRef]

46. Schimel, J. Global change: Rice, microbes and methane. Nature 2000, 403, 375-376. [CrossRef] [PubMed]

47. Xu, Z.; Zheng, X.; Wang, Y.; Han, S.; Huang, Y.; Zhu, J.; Butterbach-Bahl, K. Effects of elevated $\mathrm{CO}_{2}$ and $\mathrm{N}$ fertilization on $\mathrm{CH}_{4}$ emissions from paddy rice fields. Glob. Biogeochem. Cycles 2004, 18, 1-8. [CrossRef]

48. Gulledge, J.; Schimel, J.P. Low-concentration kinetics of atmospheric $\mathrm{CH}_{4}$ oxidation in soil and mechanism of NH4+ inhibition. Appl. Environ. Microbiol. 1998, 64, 4291-4298. [PubMed]

49. Cai, Z.; Xing, G.; Yan, X.; Xu, H.; Tsuruta, H.; Yagi, K.; Minami, K. Methane and nitrous oxide emissions from rice paddy fields as affected by nitrogen fertilizers and water management. Plant Soil 1997, 196, 7-14. [CrossRef]

50. Banger, K.; Tian, H.; Lu, C. Do nitrogen fertilizers stimulate or inhibit methane emissions from rice fields? Glob. Chang. Biol. 2012, 18, 3259-3267. [CrossRef] [PubMed]

51. Domínguez, V.; Irisarri, P.; Gonnet, S. Emisiones de óxido nitroso por suelos cultivados con arroz: Efecto de un inhibidor de la nitrificación. Agrociencia 2007, 11, 50-57.

52. Scivittaro, W.B.; Nunes, G.D.R.; Campos do Vale, M.L.; Ricordi, V.G. Nitrogen losses by ammonia volatilization and lowland rice response to NBPT urease inhibitor-treated urea. Ciênc. Rural 2010, 40, 1283-1289. [CrossRef]

53. LaHue, G.T.; Chaney, R.L.; Adviento-Borbe, M.A.A.; Linquist, B.A. Alternate wetting and drying in high yielding direct-seeded rice systems accomplished multiple environmental and agronomic objectives. Agric. Ecosyst. Environ. 2016, 229, 30-39. [CrossRef]

54. Linquist, B.A.; Anders, M.M.; Adviento-Borbe, M.A.A.; Chaney, R.L.; Nalley, L.L.; da Rosa, E.F.F.; van Kessel, C. Reducing greenhouse gas emissions, water use, and grain arsenic levels in rice systems. Glob. Chang. Biol. 2015, 21, 407-417. [CrossRef] [PubMed]

55. Xu, Y.; Ge, J.; Tian, S.; Li, S.; Nguy-Robertson, A.L.; Zhan, M.; Cao, C. Effects of water-saving irrigation practices and drought resistant rice variety on greenhouse gas emissions from a no-till paddy in the central lowlands of China. Sci. Total Environ. 2015, 505, 1043-1052. [CrossRef] [PubMed] 
56. Pandey, A.; Mai, V.T.; Vu, D.Q.; Bui, T.P.L.; Mai, T.L.A.; Jensen, L.S.; de Neergaard, A. Organic matter and water management strategies to reduce methane and nitrous oxide emissions from rice paddies in Vietnam. Agric. Ecosyst. Environ. 2014, 196, 137-146. [CrossRef]

57. Qin, Y.; Liu, S.; Guo, Y.; Liu, Q.; Zou, J. Methane and nitrous oxide emissions from organic and conventional rice cropping systems in Southeast China. Biol. Fertil. Soils 2010, 46, 825-834. [CrossRef]

58. Tarlera, S.; Capurro, M.C.; Irisarri, P.; Scavino, A.F.; Cantou, G.; Roel, A. Yield-scaled global warming potential of two irrigation management systems in a highly productive rice system. Sci. Agric. 2016, 73, 43-50. [CrossRef]

59. Yu, K. Redox Potential Control on Cumulative Global Warming Potentials from Irrigated Rice Fields. In Understanding Greenhouse Gas Emissions from Agricultural Management; Guo, L., Gunasekara, A.S., McConnell, L.L., Eds.; ACS Symposium Series 1072; ACS Publications: Washington, DC, USA, 2011; pp. 121-134. [CrossRef]

60. Minamikawa, K.; Sakai, N. The practical use of water management based on soil redox potential for decreasing methane emissions from a paddy field in Japan. Agric. Ecosyst. Environ. 2006, 116, 181-188. [CrossRef]

61. Kim, G.Y.; Gutierrez, J.; Jeong, H.C.; Lee, J.S.; Haque, M.D.M.; Kim, J.P. Effect of intermittent drainage on methane and nitrous oxide emissions under different fertilization in a temperate paddy soil during rice cultivation. J. Korean Soc. Appl. Biol. Chem. 2014, 57, 229-236. [CrossRef]

62. Shiratori, Y.; Watanabe, H.; Furukawa, Y.; Tsuruta, H.; Inubushi, K. Effectiveness of a subsurface drainage system in poorly drained paddy fields on reduction of methane emissions. J. Plant Nutr. Soil Sci. 2007, 53, 387-400. [CrossRef]

63. Lagomarsino, A.; Agnelli, A.E.; Pastorell, R.; Pallara, G.; Rasse, D.P.; Silvennoinen, H. Past water management affected GHG production and microbial community pattern in Italian rice paddy soils. Soil Biol. Biochem. 2016, 93, 17-27. [CrossRef]

64. Johnson-Beebout, S.E.; Angeles, O.R.; Alberto, M.C.R.; Buresh, R.J. Simultaneous minimization of nitrous oxide and methane emission from rice paddy soils is improbable due to redox potential changes with depth in a greenhouse experiment without plants. Geoderma 2009, 149, 45-53. [CrossRef]

65. Zou, J.; Huang, Y.; Jiang, J.; Zheng, X.; Sass, R.L. A 3-year field measurement of methane and nitrous oxide emissions from rice paddies in China: Effects of water regime, crop residue, and fertilizer application. Glob. Biogeochem. Cycles 2005, 19, GB2021. [CrossRef]

66. Mushtaq, S.; Khan, S.; Hafeez, N.; Hanjra, M.A. Does reliability of water resources matter in the adoption of water-saving irrigation practices? A case study in the Zhanghe irrigation system, China. Water Policy 2009, 11, 661-679. [CrossRef]

67. Lampayan, R.M.; Rejesus, R.M.; Singleton, G.R.; Bouman, B.A.M. Adoption and economics of alternate wetting and drying water management for irrigated lowland rice. Field Crops Res. 2015, 170, 95-108. [CrossRef]

68. Lampayan, R.M.; Bouman, B.A.M.; Flor, R.J.; Palis, F.G. Developing and disseminating alternate wetting and drying water saving technology in the Philippines. In Mitigating Water-Shortage Challenges in Rice Cultivation: Aerobic and Alternate Wetting and Drying Rice Water-Saving Technologies; Kumar, A., Ed.; IRRI, Asian Development Bank: Manila, Philippines, 2014.

69. Kürschner, E.; Henschel, C.; Hildebrandt, T.; Jülich, E.; Leineweber, M.; Paul, C. Water Saving in Rice Production-Dissemination, Adoption and Short Term Impacts of Alternate Wetting and Drying (AWD) in Bangladesh; SLE Publication Series; Humboldt Universität zu Berlin: Berlin, Germany, 2010; p. 96.

70. Carrijo, D.R.; Lundy, M.E.; Linquist, B.A. Rice yields and wáter use under alternate wetting and drying irrigation: A meta-analysis. Field Crops Res. 2017, 203, 173-180. [CrossRef]

71. Li, Y.H.; Barker, R. Increasing water productivity for paddy irrigation in China. Paddy Water Environ. 2004, 2, 187-193. [CrossRef]

72. Kurtz, D.; Fedre, J. El cultivo del arroz y el ambiente. In Guía de Buenas Prácticas Agrícolas Para el Cultivo de Arroz en Corrientes, 2nd ed.; Moulin, J., Araujo, J., Kruger, J., Eds.; 2016. Available online: http:/ /www. acpaarrozcorrientes.org.ar/Paginas/GUIA.BPA.ARROZ.CTES\%20.2016.pdf (accessed on 28 February 2018).

73. FNA (Federación Nacional de Arroceros). ADOPCIÓN MASIVA DE TECNOLOGÍA. Available online: http:/ / www.fedearroz.com.co/docs/Guia_de_trabajo_baja.pdf (accessed on 10 April 2017). 
74. DANE (Departamento Administrativo Nacional de Estadística). Federacion Nacional de Arroceros \& Fondo Nacional del Arroz. IV Censo Nacional Arrocero 2016. Available online: http: / www.fedearroz.com.co/ doc_economia/Libro\%20zona\%20Llanos.pdf (accessed on 10 April 2017).

75. Zorrilla, G.; Martínez, C.; Berrío, L.; Corredor, E.; Carmona, L.; Pulver, E. Improving Rice Production Systems in Latin America and the Caribbean. In Eco-Efficiency: From Vision to Reality; Hershey, C.H., Neate, P., Eds.; Issues in Tropical Agriculture Series; CIAT Publication No. 381; Centro Internacional de Agricultura Tropical (CIAT): Valle del Cauca, Colombia, 2012.

76. Yoshida, S. Fundamentals of Rice Science. Available online: http://books.irri.org/9711040522_content.pdf (accessed on 6 November 2017).

77. Calvert, L.A.; Sanint, L.R.; Châtel, M.; Izquierdo, J. Rice production in Latin America at critical crossroads. Int. Rice Comm. Newsl. 2006, 55, 66-73.

78. Dobermann, A.; Fairhurst, T.H. Rice straw management. Better Crops Int. 2002, 16, 7-11.

79. Buresh, R.; Sayre, K. Implications of straw removal on soil fertility and sustainability. In Proceedings of the 2007 Expert Consultation on Biofuels, IRRI, Los Banos, Philippines, 27-29 August 2007; pp. 34-44.

80. Zschornack, T.; Bayer, C.; Acordi, Z.J.; Costa, B.V.F.; Anghinoni, I. Mitigation of methane and nitrous oxide emissions from flood-irrigated rice by no incorporation of winter crop residues into the soil. Rev. Bras. Ciênc. Solo 2011, 35, 623-634. [CrossRef]

81. Arai, H.; Hosen, Y.; Pham, H.V.; Truong, N.T.; Nguyen, C.H.; Inubushi, K. Greenhouse gas emissions from rice straw burning and straw-mushroom cultivation in a triple rice cropping system in the Mekong Delta. J. Plant Nutr. Soil Sci. 2015, 61, 719-735. [CrossRef]

82. Gadde, B.; Bonnet, S.; Menke, C.; Garivait, S. Air pollutant emissions from rice straw open field burning in India, Thailand and the Philippines. Environ. Pollut. 2009, 157, 1554-1558. [CrossRef] [PubMed]

83. Xu, H.; Cai, Z.C.; Jia, Z.J.; Tsuruta, H. Effect of land management in winter crop season on CH4 emission during the following flooded and rice-growing period. Nutr. Cycl. Agroecosyst. 2000, 58, 327-332. [CrossRef]

84. Sander, B.O.; Samson, M.; Buresh, R.J. Methane and nitrous oxide emissions from flooded rice fields as affected by water and straw management between rice crops. Geoderma 2014, 235, 355-362. [CrossRef]

85. Cochran, V.L.; Sparrow, E.B.; Schlender, S.F.; Knight, C.K. Long-term tillage and crop residue management in the subarctic: Fluxes of methane and nitrous oxide. Can. J. Soil Sci. 1997, 77, 565-570. [CrossRef]

86. Sass, R.L.; Fisher, F.M.; Harcombe, P.A.; Turne, F.T. Mitigation of methane emissions from rice fields: Possible adverse effects of incorporated rice straw. Glob. Biogeochem. Cycles 1991, 5, 275-287. [CrossRef]

87. Bossio, D.A.; Horwath, W.R.; Mutters, R.G.; van Kessel, C. Methane pool and flux dynamics in a rice field following straw incorporation. Soil Biol. Biochem. 1999, 31, 1313-1322. [CrossRef]

88. Wang, W.; Lai, D.Y.F.; Wang, C.; Pan, T.; Zeng, C. Effects of rice straw incorporation on active soil organic carbon pools in a subtropical paddy field. Soil Tillage Res. 2015, 152, 8-16. [CrossRef]

89. Wang, W.; Lai, D.Y.F.; Sardans, J.; Wang, C.; Datta, A.; Pan, T.; Zenga, C.; Bartrons, M.; Peñuelas, J. Rice straw incorporation affects global warming potential differently in early vs. late cropping season in Southeastern China. Field Crops Res. 2015, 181, 42-51. [CrossRef]

90. Gaihre, Y.K.; Wassmann, R.; Villegas-Pangga, G. Impact of elevated temperatures on greenhouse gas emissions in rice systems: Interaction with straw incorporation studied in a growth chamber experiment. Plant Soil 2013, 373, 857-875. [CrossRef]

91. Sigren, L.K.; Byrd, G.T.; Fisher, F.M.; Sass, R.L. Comparison of soil acetate concentrations and methane production, transport and emission in two rice cultivars. Glob. Biogeochem. Cycles 1997, 11, 1-14. [CrossRef]

92. Wassmann, R.; Neue, H.; Lantin, R.S.; Buendia, L.V.; Rennenberg, H. Characterization of methane emissions from rice fields in Asia. I. Comparison among field sites in five countries. Nutr. Cycl. Agroecosyst. 2000, 58, 1-12. [CrossRef]

93. Simmonds, M.B.; Anders, M.; Adviento-Borbe, M.A.A.; van Kessel, C.; McClung, A.; Linquist, B.A. Seasonal methane and nitrous oxide emissions of several rice cultivars in direct-seeded systems. J. Environ. Qual. 2015, 44, 103-114. [CrossRef] [PubMed]

94. Wang, B.; Neue, H.U.; Samonte, H.P. Effect of cultivar difference ('IR72', 'IR65598' and 'Dular') on methane emission. Agric. Ecosyst. Environ. 1997, 62, 31-40. [CrossRef]

95. Mariko, S.; Harazono, Y.; Owa, N.; Nouchi, I. Methane in flooded soil water and the emission through rice plants to the atmosphere. Environ. Exp. Bot. 1991, 31, 343-350. [CrossRef] 
96. Gogoi, N.; Baruah, K.; Gogoi, B.; Gupta, P.K. Methane emission from two different rice ecosystems at lower Brahmaputra valley zone of North East India. Appl. Ecol. Environ. Res. 2008, 6, 99-112. [CrossRef]

97. Su, J.; Hu, C.; Yan, X.; Jin, Y.; Chen, Z.; Guan, Q.; Wang, Y.; Zhong, D.; Jansson, C.; Wang, F.; et al. Expression of barley SUSIBA2 transcription factor yields high-starch low-methane rice. Nature 2015, 523, 602-606. [CrossRef] [PubMed]

98. Badawi, T.; Ghanem, S.A. Water use efficiency in rice Culture. CIHEAM Options Mediterr. 2001, 40, 39-45.

99. Wassmann, R.; Schütz, H.; Papen, H.; Rennenberg, H.; Wolfgang, S.; Aiguo, D.; Renxing, S.; Xingjian, S.; Mingxing, W. Quantification of methane emissions from Chinese rice fields (Zhejiang Province) as influenced by fertilizer treatment. Biogeochemistry 1993, 11, 83-101. [CrossRef]

100. Yan, X.; Shi, S.; Du, L.; Xing, G. Pathways of $\mathrm{N}_{2} \mathrm{O}$ emission from rice paddy soil. Soil Biol. Biochem. 2000, 32, 437-440. [CrossRef]

101. Zheng, H.; Huang, H.; Yao, L.; Liu, J.; He, H.; Tang, J. Impacts of rice varieties and management on yield-scaled greenhouse gas emissions from rice fields in China: A meta-analysis. Biogeosciences 2014, 11, 3685-3693. [CrossRef]

102. Gogoi, N.; Baruah, K.; Gupta, P.K. Selection of rice genotypes for lower methane emission. Agron. Sustain. Dev. 2008, 28, 181-186. [CrossRef]

103. Scopel, E.; Bernard, T.; Ribeiro, M.F.S.; Séguy, L.; Denardin, J.E.; Kochhann, R.A. Direct seeding mulch-based cropping systems (DMC) in Latin America in Latin America. New directions for a diverse planet. In Proceedings of the 4th International Crop Science Congress, Brisbane, Australia, 26 September1 October 2004.

104. Yamano, T.; Arouna, A.; Labarta, R.A.; Huelgas, Z.M. Adoption and impacts of international rice research technologies. Glob. Food Secur. 2016, 8, 1-8. [CrossRef]

105. Bhushan, L.; Ladha, J.K.; Gupta, R.K.; Singh, S.; Tirol-Padre, A.; Saharawat, Y.S.; Gathala, M.; Pathak, H. Saving of water and labor in a rice-wheat system with no-tillage and direct seeding technologies. Agron. J. 2007, 99, 1288-1296. [CrossRef]

106. DeAngelo, B.J.; de la Chesnaye, F.C.; Beach, R.H.; Sommer, A.; Murray, B.C. Methane and nitrous oxide mitigation in agriculture. Energy J. 2006, 27, 89-108. [CrossRef]

107. Kumar, V.; Ladha, J.K. Direct Seeding of Rice: Recent Developments and Future Research Needs. Adv. Agron. 2011, 111, 297-413.

108. Kurtz, D.; Ligier, H. Estimaciones de Las Emisiones de Metano en Suelos Dedicados al Cultivo de Arroz en la Provincia de Corrientes, 2014. Avaliable online: https://ced.agro.uba.ar/ubatic/sites/default/files/files / Servicios\%20ecosistemicos/Eje\%20Tematico\%202.pdf (accessed on 30 October 2017). 